\title{
Performance of Crusher Dust in High Plastic Gravel Soils As Road Construction Material
}

\author{
*P.V.V. Satyanarayana, **P.Raghu, **R.Ashok Kumar, **N.Pradeep. \\ *Professor, **Post graduate students, Dept. of Civil Engineering, Andhra university.
}

\begin{abstract}
The performance of Flexible Pavement depends on the functions of the component layers especially Sub-base layers. Generally Sub-base layers are made up of natural soils like Gravels. Frequently gravel soils composed of high amount of fines which causes plasticity characteristics with adsorption of moisture under heavy loads and repeated traffic. Excess deformation leading several failure which require huge investment of money for their repairs. To reduce the excess deformation of the gravel soils and to increase the life period of the pavement there is a need to arrest their plastic characteristics and stabilization is one such techniques to improve the gravel soils by addition of industrial wastes. In this connection Crusher Dust has been selected as a Stabilizer to improve their qualities. Various percentage of Crusher Dust was added to gravel soil and tests like Plasticity, Compaction and Strength tests were conducted. By the addition of Crusher Dust Plasticity Characteristics were reduced and CBR values were improved. Addition of $25 \%$ of Crusher Dust make the mixes low-plastic and 35\% of Crusher Dust make the mixes non-plastic, where high CBR values attained. Hence from the test results it is identified that addition of $25 \%-35 \%$ of Crusher Dust make the gravel soils meet the specification of MORTH as a sub-base material.
\end{abstract}

Keywords: Gravel, crusher dust, CBR, MORTH.

\section{Introduction:}

Road networking is one of the infrastructure which is required for the economic development of a country. In India Road net working includes connecting of urban \& rural areas through $\mathrm{NH}$, SH \& MDR as other rural and urban roads. To meet the demands government has been running construction of flexible pavements. The component layer like sub-base is generally made up of locally available natural gravelly soils. The presence of plastic fines often causes excess deformations under repeated locations and poor drainage causing loss in strength and happened the usual practice is stabilisation with various industrial wastes. In this connection crusher dust is an industrial waste obtained from the crushed stone plants.

Crusher dust can be advantageously used in reinforced earth retaining walls, reinforced soil beds and reinforced flexible pavements as a fill material due to its stability, free draining nature and good frictional characteristics with synthetic reinforcement. Soosan et.al (2001) identified that crusher dust exhibits high shear strength and is beneficial for its use as a geotechnical material. Sridharan et.al. (2005) studied the effect of quarry Dust in highway construction that CBR and angle of shearing resistance values are steadily increased with increase the percentage of Quarry Dust. Praveen Kumar et.al(2006) conducted CBR and tri-axial tests on fly ash, coarse sand, stone dust and river bed materials for their use in the sub base materials of the flexible pavements. Shanker and Ali (1992) have studied engineering properties of rock flour and reported that the rock flour can be used as alternative material in place of sand in concrete based on grain size data. Rao, et al (1996) have reported that sand can be replaced fully with rock flour. Wood S.A et.al reported that the quality of crushed stone dust depends on the type of parent materials. In this an attempt is made to study the effect of Crusher Dust and Crushed Stone Mixes in studying there, plasticity Compaction Characteristics and strength characteristics.

Some of the researchers on utilization of Gravel and morrum in Geotechnical applications are Ramana Murthy. V. et.al, (2003,2004), Hausmann (1990), Prakash et.al, (1993), Gourley C. S et.al(1997), Nunan T.A et.al, (1990), Thom N. H et.al, (1988), Jain P.K et.al, (2010) studied the stabilization of morrum and their strength characteristics in terms of CBR as a Road Construction material.

\section{Materials:}

Two Gravel samples were collected from various sources of North coastal districts of Andhra Pradesh i.e., Paderu, and Srikakulam. The collected Gravel soil samples from the sources can be designated as Paderu as PG, Srikakulam as SG. These samples were subjected for Geotechnical Characterization such as Gradation, Compaction and Strength as per IS: 2720 and the results are listed below in the tables 1-4 and figures 1\&2. 
2.1 Geotechnical Characteristics of Gravels:

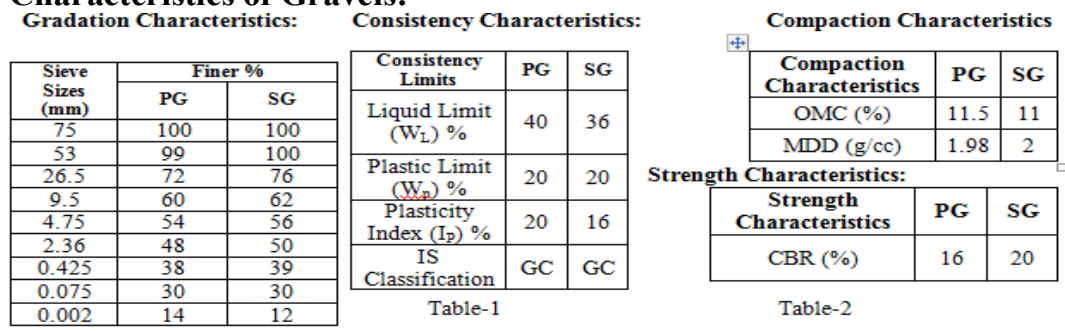
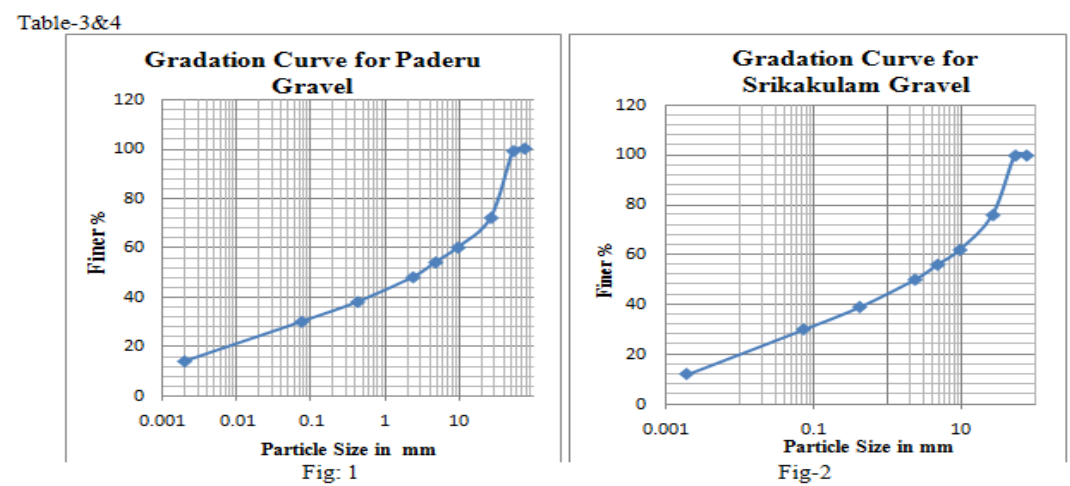

Gravel soils collected from Paderu (PG) and Srikakulam (SG) have the following identifications based on their Geotechnical Characteristics.

From the gradation test analysis all the two gravel soils consisted gravel particles $(>4.75 \mathrm{~mm})$ as major constituent and fines $(<0.075 \mathrm{~mm})$ are varying $30 \%$, out of which silt particles are $16-18 \%$ and Clay particles are $12-14 \%$. Comparing the Gradation particles of these soils with MORTH'S gradation for Sub-base material. Most of these are accepting Grade 1 of close gradation except the percentage of fines. From the consistency data Paderu and Srikakulam Gravels exhibited high Plastic characteristics i.e, $\mathrm{I}_{\mathrm{P}}>15$ and Intermediate compressible characteristics i.e, $\mathrm{W}_{\mathrm{L}} 35-50$. According MORTH a material is to be used as a sub-base material it has $\mathrm{I}_{\mathrm{P}}<6$ and $\mathrm{W}_{\mathrm{L}}<25$. From the compaction test data it is identified that Paderu and Srikakulam Soils attained low maximum dry densities with high optimum moisture contents. For explaining strength characteristics CBR value have chosen. From the test results it is identified that low CBR values obtained for Paderu and Srikakulam soil have less values to suit as sub base material $(\mathrm{CBR}<20 \&<30)$ from MORTH specifications as per Grade 1 to 3 .

To meet the MORTH specifications about close graded sub-base material it is necessary to modify the fines with respect to Plasticity i.e, $\mathrm{I}_{\mathrm{P}}<6$ and Liquid Limit i.e, $\mathrm{W}_{\mathrm{L}}<25 \%$. In this connection Crusher dust has been selected as a stabilizer and obtained from the nearby Crushing plants in Anakapalli to study the interaction between Crusher Dust particles and Fines with Gravel soils.

\subsection{Crusher Dust:}

Crusher Dust was obtained from local stone crushing plants near Anakapalli, Visakhapatnam district, Andhra Pradesh. The sample subjected to various geotechnical characterizations. The results are shown in table5 .

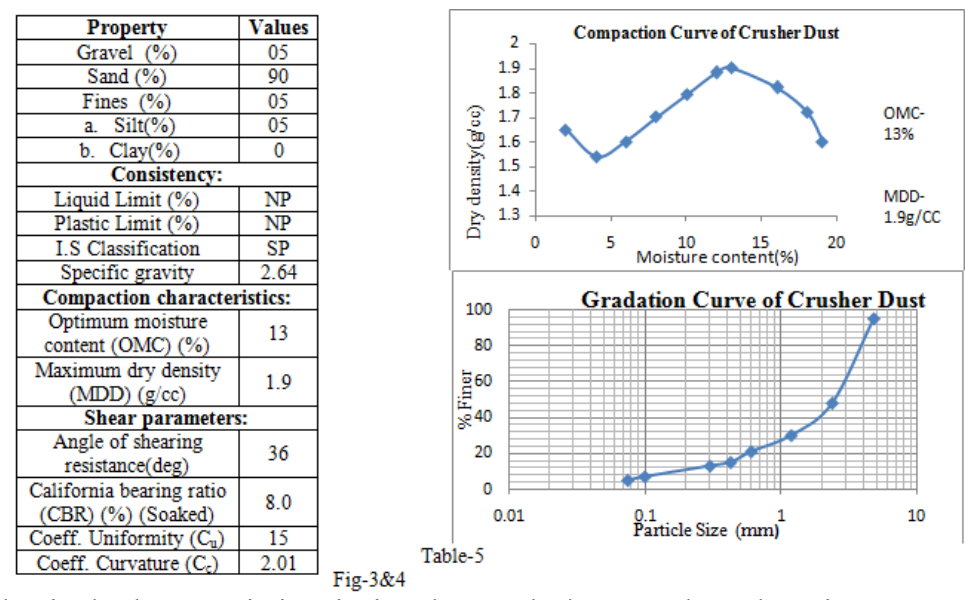

From the physical characteristics it is observed that crusher dust is a grey color fine aggregate consisting of medium to fine sand size particles and of angular shape with rough surface texture. From the consistency data it is non-plastic and incompressible in nature. From the compaction curve it can be seen that 
crusher dust attains higher densities with wider variation in moisture content and also increase in workability at higher moisture contents.

\section{Results And Discussions:}

\subsection{Plasticity Characteristics of PG and SG:}

Plasticity Characteristics and their deformation can be betterly explained with Index Properties like Liquid Limit $\left(\mathrm{W}_{\mathrm{L}}\right)$, Plastic Limit $\left(\mathrm{W}_{\mathrm{P}}\right)$, and Plasticity Index $\left(\mathrm{I}_{\mathrm{P}}\right)$. To know the results of gravel Crusher Dust mixes the Material passing through $425 \mu \mathrm{m}$ of Crusher dust Gravel mixes have taken at various percentages of crusher dust have been subjected to consistency limits such as Liquid Limit, Plastic Limit and Plasticity Index etc as per IS: 2720 and the results are shown in table- 6 and fig-5\&6

\section{Plasticity Characteristics of PG:}

\begin{tabular}{|c|c|c|c|}
\hline $\begin{array}{c}\text { Crusher } \\
\text { Dust } \\
(\%)\end{array}$ & $\begin{array}{c}\text { Liquid } \\
\text { limit } \\
(\%) \\
\left(\mathbf{W}_{\mathrm{L}}\right)\end{array}$ & $\begin{array}{c}\text { Plastic } \\
\text { Limit } \\
(\%) \\
\left(\mathbf{W}_{\mathrm{P}}\right)\end{array}$ & $\begin{array}{c}\text { Plasticity } \\
\text { Index } \\
\left(\mathbf{I}_{\mathrm{P}}\right)\end{array}$ \\
\hline 0 & 40 & 20 & 20 \\
\hline 5 & 38 & 19.5 & 18.5 \\
\hline 10 & 36 & 19 & 15 \\
\hline 15 & 33 & 19.5 & 12.5 \\
\hline 20 & 30 & 20 & 10 \\
\hline 25 & 26 & 21 & 5 \\
\hline 30 & 23 & 20 & 3 \\
\hline 35 & 22 & NP & NP \\
\hline 40 & NP & NP & NP \\
\hline 45 & NP & NP & NP \\
\hline 50 & NP & NP & NP \\
\hline & Table-6 & \\
& &
\end{tabular}

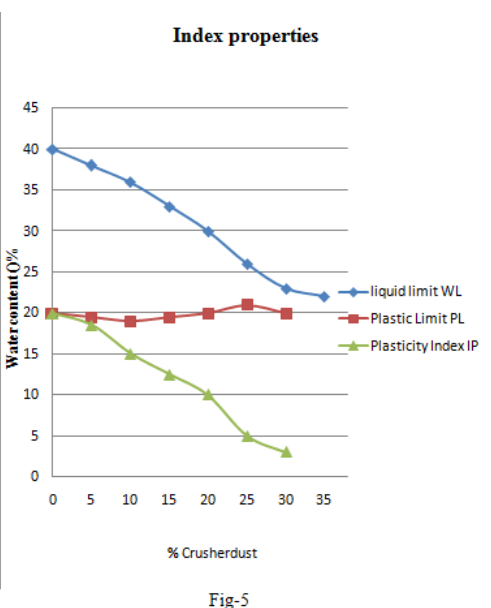

Plasticity Characteristics of SG:

\begin{tabular}{|c|c|c|c|}
\hline $\begin{array}{c}\text { Crusher } \\
\text { Dust } \\
(\%)\end{array}$ & $\begin{array}{c}\text { Liquid } \\
\text { limit } \\
\mathbf{W}_{\mathbf{L}}\end{array}$ & $\begin{array}{c}\text { Plastic } \\
\text { Limit } \\
\mathbf{P}_{\mathbf{L}}\end{array}$ & $\begin{array}{c}\text { Plasticity } \\
\text { Index } \mathbf{I}_{\mathrm{P}}\end{array}$ \\
\hline 0 & 36 & 20 & 16 \\
\hline 5 & 34 & 19.5 & 14.5 \\
\hline 10 & 31 & 19 & 12 \\
\hline 15 & 28 & 18.5 & 9.5 \\
\hline 20 & 25 & 18 & 7 \\
\hline 25 & 22 & 17 & 5 \\
\hline 30 & 21 & 17 & 4 \\
\hline 35 & NP & NP & NP \\
\hline 40 & NP & NP & NP \\
\hline 45 & NP & NP & NP \\
\hline 50 & NP & NP & NP \\
\hline \multicolumn{4}{|c|}{ Table-7 } \\
\hline
\end{tabular}

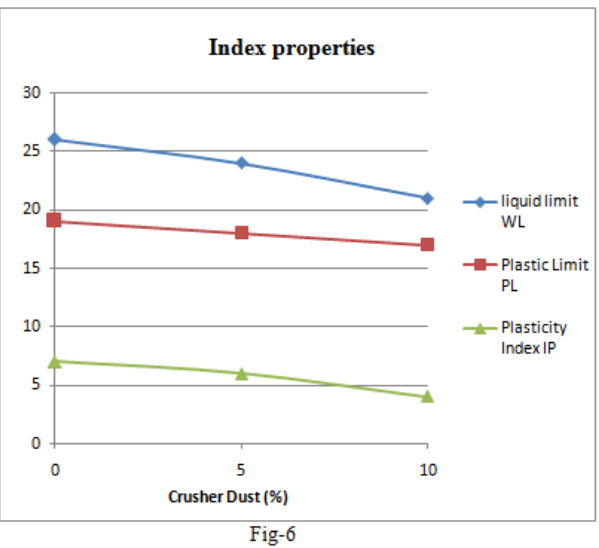

From the test data it is observed that addition of crusher dust decreases Liquid Limit, Plastic Limit and Plasticity Index values. The trend has continued upto $30 \%$ of Crusher dust; beyond this a true non-plastic behaviour was observed. Further increase in percentage of crusher dust make the Crusher dust and fines of gravel maintains the behaviour of crusher dust. The plasticity characteristics of the gravel soils purely depend on the percentage of fines $(<425 \mu \mathrm{m})$. In the given soil composition the percentage of fines are less and the main contribution for development of plasticity characteristics are due to clay content is also less. This composition makes the soil to attain a low compressible $\left(\mathrm{W}_{\mathrm{L}}<25\right)$ and low to non Plastic $\left(\mathrm{I}_{\mathrm{P}}<6\right)$. Due to nature of soil a dosage of Crusher dust dosage of 35\% made crusher dust soil mixes Non-Plastic and 30\% dosage of Crusher dust soils made the Crusher dust soil Mixes a low plastic $\left(\mathrm{I}_{\mathrm{P}}<6\right)$.

\subsection{Compaction Characteristics :}

Various percentages of Crusher dust was added to Gravel soils at their dry weights and IS heavy compaction test was performed as per IS: 2720 and the results are listed below in table-8\&9 and Fig-7-10. 


\section{Compaction Characteristics PG:}

\begin{tabular}{|c|c|c|}
\hline $\begin{array}{c}\text { Crusher } \\
\text { Dust (\%) }\end{array}$ & $\begin{array}{c}\text { OMC } \\
\text { (\%) }\end{array}$ & $\begin{array}{c}\text { MDD } \\
\text { (g/cc) }\end{array}$ \\
\hline 0 & 11.5 & 1.98 \\
\hline 5 & 11.2 & 2 \\
\hline 10 & 11 & 2.02 \\
\hline 15 & 10.7 & 2.05 \\
\hline 20 & 10.4 & 2.07 \\
\hline 25 & 10 & 2.09 \\
\hline 30 & 9.6 & 2.12 \\
\hline 35 & 9 & 2.13 \\
\hline 40 & 8.5 & 2.11 \\
\hline 45 & 8.2 & 2.09 \\
\hline 50 & 7.8 & 2.06 \\
\hline
\end{tabular}

Table-8
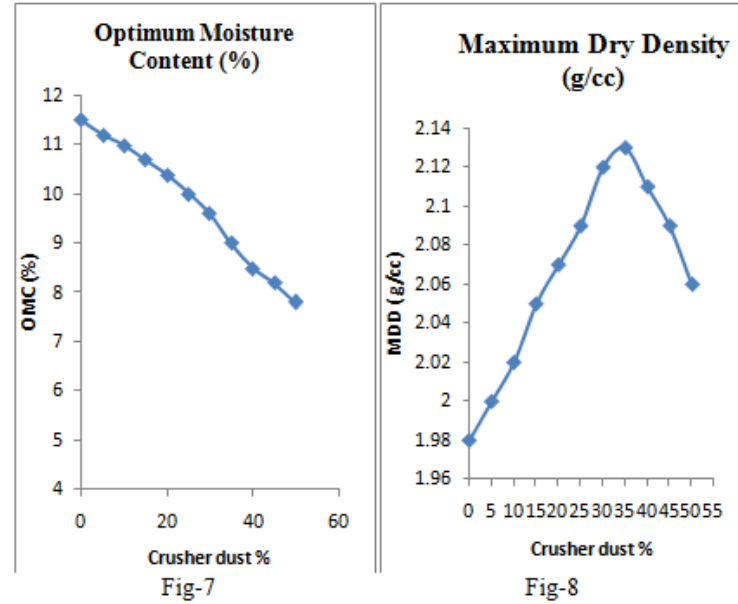

\section{Compaction Characteristics SG:}

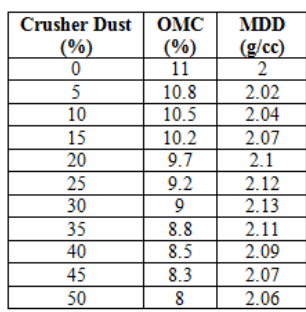

Table-9

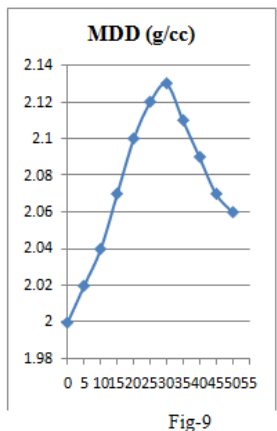

Fig-9

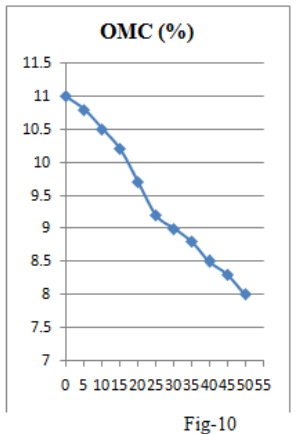

Fig-10

From the test results it is identified that as the percentage of crusher dust is increasing the optimum moisture content values are continuously decreasing, whereas the Maximum Dry Density values are continuously increasing upto 30-35\% and then decreasing. The decrease in optimum Moisture Contents are due to replacement of Silt and Clay particles by Crusher Dust particles which reduces the intake of Moisture compared to Crusher Dust particles and increase in dry densities are due to occupation of more solids with respect to interaction of Crusher Dust and fines of gravel particles upto 30-35\%. Further increasing the dosage the occupation of majority of the fines by the Crusher Dust particles attaining the behaviour of Crusher Dust.

\subsection{California Bearing Ratio (CBR) PG:}

Various percentages of Crusher dust was added to Gravel soils at their dry weights and California Bearing test was performed on soaked samples after four days soaking period compacted at their maximum dry densities as per IS: 2720 and the results are listed below in table-10\&11 and Fig-11\&12

\begin{tabular}{|c|c|}
\hline $\begin{array}{c}\text { Crusher Dust } \\
\text { (\%) }\end{array}$ & CBR (\%) \\
\hline 0 & 16 \\
\hline 5 & 18 \\
\hline 10 & 20 \\
\hline 15 & 23 \\
\hline 20 & 26 \\
\hline 25 & 30 \\
\hline 30 & 35 \\
\hline 35 & 38 \\
\hline 40 & 34 \\
\hline 45 & 30 \\
\hline 50 & 25 \\
\hline
\end{tabular}

Table: 10
CBR

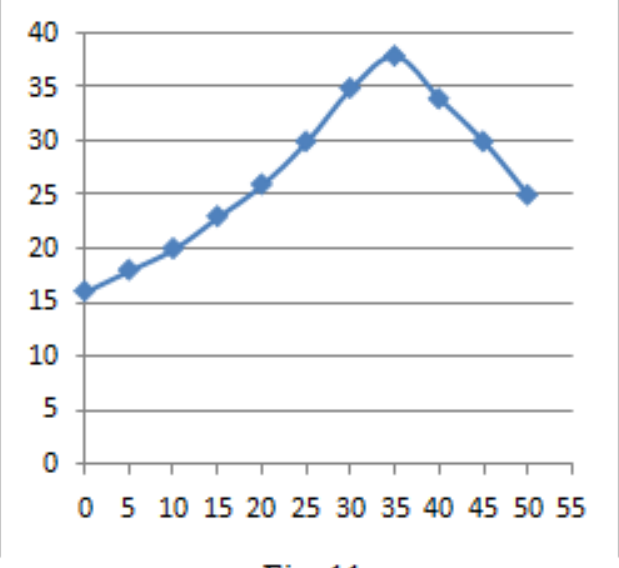

Fig: 11 
California Bearing Ratio (CBR) SG:

\begin{tabular}{|c|c|}
\hline Crusher Dust (\%) & CBR (\%) \\
\hline 0 & 20 \\
\hline 5 & 22 \\
\hline 10 & 25 \\
\hline 15 & 28 \\
\hline 20 & 32 \\
\hline 25 & 36 \\
\hline 30 & 38 \\
\hline 35 & 35 \\
\hline 40 & 30 \\
\hline 45 & 27 \\
\hline 50 & 25 \\
\hline
\end{tabular}

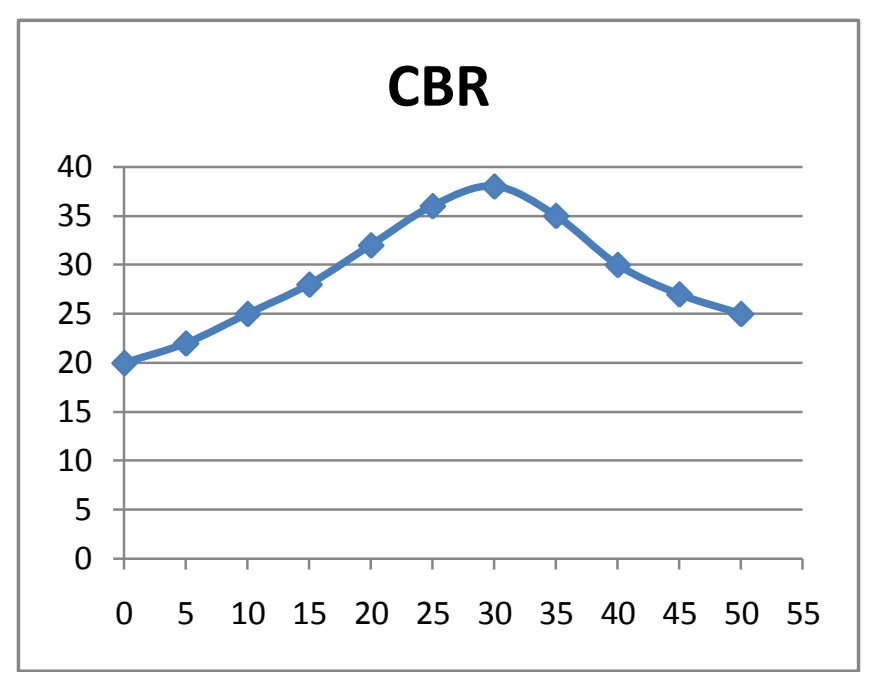

Table-11

Fig-12

As the percentage of Crusher dust is increasing upto CBR values are increasing upto 35\% and then decreasing. Attainment of maximum values at 30-35\% doses are due to more solids occupied in the given volume due to the effective interaction between the Crusher Dust particles and Fine and coarser particles of Gravel soil, offers more shearing resistance against compression.

\section{Conclusions:}

By observing the test results of crusher dust and gravel mixes high plastic and intermediate compressible gravelly soils require more dosage of Crusher dust and to meet the specifications of MORTH grade-I sub-base materials for close grading. It is also identified that $25 \%-35 \%$ dosage of Crusher dust yield high CBR values and made them non-plastic.

\section{References:}

[1]. IS 2720: Part 4: 1985 Methods of Test for Soils - Part 4: Grain Size Analysis.

[2]. IS 2720: Part 8: 1987 Methods of Test for Soils - Part 8: Determination of water Content and Dry Density Relation Using Heavy Compaction.

[3]. IS 2720: Part 16: 1987 Methods of Test for Soil - Part 16: Laboratory Determination of CBR.

[4]. Gourley C. S. and Greening, P. A. K. (1997), "Use of Sub-standard Laterite Gravels as Road Base Materials in Southern Africa", International Symposium on Thin Pavements, Surface Treatments and Unbound Roads, University of New Brunswick, Canada.

[5]. Hausmann, M.R. (1990): Engineering Principles of Ground Modification, McGraw Hill Book Company, New Delhi.

[6]. MORTH specification For Road and Bridge Works, published by IRC 2001.

[7]. Nagaraj T.S. 2000. Proportioning Concrete Mix with Rock Dust as Fine Aggregate. CE and CR Journal. pp. 27-31.

[8]. Nunan T. A. and Humphrey D. N. (1990)," A Review and Experimentation of Gravel Stabilization Methods, executive”, Technical services division, Technical report 90-2, Department of Civil Engineering, University of Maine, Orono, Maine.

[9]. Pradeep Muley, Jain P.K (2010) " Experimental studies on utilization of murrum as hard shoulder material”, International Journal of engineering Science and technology. Vol. 2(9), 2010, p. no. 4896-4901.

[10]. Praveen Kumar, Satish Chandra and Vishal, R(2006) "comparative study of different Sub-base material journal of materials" in civil engineering vol 18(4) 576-580.

[11]. Ramana Murthy, V. and Hari Krishna, P. (2003): Influence of Inorganic Additives on Properties of Morrum Soils Used in Pavement Construction, National Seminar on Recent Advances in Civil Engineering, KITS - Warangal, pp. II 17 -II 23.

[12]. Ramana Murthy V et.al, (2004) "Cement stabilized WBM roads for Rural India. Vol.1 IGC 2004 p. no 510-513."

[13]. Rao, G.T and Andal, T(1996), “A Study on Behaviour of Concrete With Stone Sand Replacing River Sand”, National Conference on Alternate Construction Materials in Civil Engineering", Hamirpur, pp. 196-201.

[14]. Shankar, N.B and Ali, Md (1992), "Engineering Properties of Rock Flour", National Conference on Cement and Building Materials from Industrial Waste, pp. 167-172.

[15]. Soosan, T.G., Jose, B.T. and Abraham, B.M.(2001) Use of Crusher dust in embankment and highway construction, Proceedings of Indian Geo-Technical Conference, December, Indore, pp. 274-277.

[16]. Sridharan, A. And Soosan, T.,G. (2005),"utilization of crusher dust to improve the geotechnical properties of soil in highway construction", Canadian Geotechnical Journal, Vol. 28, pp. 391-400.

[17]. Thom, N. H., and Brown S. F. (1988), "The Effect of Grading and Density on the Mechanical Properties of a Crushed Dolomitic Limestone", Proceedings of the 14th Australian Road Research Board Conference, Sydney, Part 7, pp. 94-100.

[18]. Wood S.A and Mareck C. R(1993) Recovery and utilization of quarry by-products for construction of highway facilities, federal administration, Denver, Colorado. 